\title{
How to strengthen the connection between research and teaching in undergraduate \\ university education
}

Elsen, G.M.F.; Visser-Wijnveen, G.J.; Rijst, R.M. van der; Driel, J.H. van

\section{Citation}

Elsen, G. M. F., Visser-Wijnveen, G. J., Rijst, R. M. van der, \& Driel, J. H. van. (2009). How to strengthen the connection between research and teaching in undergraduate university education. Higher Education Quarterly, 63(1), 64-85.

doi:10.1111/j.1468-2273.2008.00411.x

Version:

License:

Downloaded from: $\quad$ https://hdl.handle.net/1887/86916

Note: To cite this publication please use the final published version (if applicable). 


\title{
How to Strengthen the Connection between
} Research and Teaching in Undergraduate University Education

\author{
Mariken (G.M.F.) Elsen; NWO - Netherlands Organisation for \\ Scientific Research, The Hague \\ Gerda J. Visser-Wijnveen, Roeland M. van der Rijst, \\ Jan H. van Driel; ICLON - Leiden University Graduate School \\ of Teaching, The Netherlands
}

\begin{abstract}
This paper explores how to strengthen the research-teaching nexus in university education, in particular, how to improve the relation between policy and practice. The focus is on courses and curricula for undergraduate students. From a review of policy documents and research literature, it appeared that the research-teaching nexus can be shaped according to two dimensions. One concerns an emphasis on either the research content and products, or the research processes and problems; the other concerns the role of students as either learning existing insights, or as 'participants in research' who contribute to insights which are new to the field (e.g., by conducting research themselves). It is concluded that if a university chooses to strengthen the research-teaching nexus in undergraduate curricula, this implies involving students more often in the role of participants in research.
\end{abstract}

\section{Introduction}

The identity or mission of many universities is traditionally based on the connection between research and teaching, as advocated, for instance, by Von Humboldt in the $19^{\text {th }}$ century (Simons $\&$ Elen, 2007). For various reasons, however, such as the 'massification' of higher education since the 1960s, research and teaching appear to have been separated. Recent 
systems of accountability and funding mechanisms, and related management strategies, have further contributed to a situation in many universities where teaching and research are organised and treated separately (Colbeck, 1998). Recently, influenced by the Lisbon agenda and the Bologna process, higher education institutes have been challenged to reconsider their identity, or mission. In this context, the connection between teaching and research has gained renewed attention as it seems to offer universities a possibility to distinguish themselves from other higher education institutes, which are primarily or exclusively focused on education. For instance, a multidisciplinary seminar on 'Research-based teaching in higher education' was organised by the so-called League of European Research Universities (LERU), in March 2005 in Helsinki. It seems, however, that there is a gap between the ideas expressed in current policy documents about strengthening the connection between research and teaching and the practice of university curricula and courses.

This study aims to contribute to the current debate on the researchteaching nexus; in particular, to improve the relation between policy and practice, focusing on courses and curricula at the undergraduate level. First, current policy documents of various universities were reviewed in which the research-teaching nexus is addressed. Next, the research literature was examined to define the meaning and identify characteristics of the research-teaching nexus in university education. In this literature, a framework was found that is specifically designed to analyse the ways in which research and teaching are connected in university curricula (Healey, 2005). This framework was then used to explore its potential for the analysis and design of courses and curricula, both by policymakers and academic staff. Elaborating on this, possibilities are discussed for improving the connection between policy and practice. The general question guiding this study was, How can the research-teaching nexus be strengthened in university education?

\section{The research-teaching nexus in policy documents of universities}

In 2002, the League of European Research Universities (LERU) was founded aiming to restore Europe's pre-eminent position in basic research. Policy documents of member universities often contain statements which address the research-teaching nexus. For example, on the website of the University of Helsinki, it says: 'Scientific research of high standard carried out in the faculties and departments of 
multidisciplinary universities provides fertile ground for teaching based on research and social interaction.' (University of Helsinki, 2007). In a recent policy document, the education profile of Leiden University, another founding member of LERU, is formulated as follows: 'Education is inspired by research, and is aimed to bring the students to the frontiers of knowledge, and provide them with an understanding of the central problems and procedures which are characteristics of fundamental academic research' (Leiden University, 2004). As another example, the University of Oxford, in its Academic Strategy - A Green Paper (2005) states that it 'is a community of scholars dedicated to the discovery and dissemination of knowledge, disinterested inquiry, and engagement with problems of national and global significance. Its objectives are to [ . . ] provide an exceptional education for both undergraduates and graduates, characterised by the close contact of students with distinguished scholars in nurturing collegiate and departmental communities'. Although all these documents emphasise the connection between research and teaching they also place different emphases on the research process (Leiden), the research outcomes (Helsinki) and the social context (i.e., community of scholars) in which research takes place (Oxford).

The latter element is also emphasised in the 'blueprint' for North American research universities, written by the Boyer Commission on Educating Undergraduates, which represents 125 research universities, including Harvard, MIT, Princeton, Stanford, Berkeley and Yale (Boyer Commission, 1998). According to the Boyer Commission, a student in a research university, among other things, has the

opportunity for work with talented senior researchers to help and guide the student's efforts. [ ...] The research university must facilitate inquiry in such contexts as the library, the laboratory, the computer, and the studio, with the expectation that senior learners, that is, professors, will be students' companions and guides. The research university owes every student an integrated educational experience in which the totality is deeper and more comprehensive than can be measured by earned credits. (Boyer Commission, 1998: 13)

Concluding this brief description of the policies of European and North American research universities, it appears that these policies point to certain ideas about the research-teaching nexus; in particular, that students should acquire an understanding of recent research outcomes in their field. Second, the curriculum should be inspired by research conducted by the academics of the institute, who, preferably, are distinguished researchers in the areas they teach. Third, students should be 
provided with opportunities to conduct research and become members of disciplinary communities or 'families' as early as possible.

However, policy documents do not offer a clear picture of what should be done to realise the policy at the level of the curricula of various disciplines. How, for instance, can the undergraduate phase gradually prepare all students for, and engage them in, academic research? It also remains unclear what students and academic staff are expected to do at the course level to strengthen the research-teaching nexus, and what the affective and cognitive outcomes of strengthening the nexus might be. To answer such questions, the research literature on the research-teaching nexus was examined. The aim was to get a more comprehensive picture of what the research-teaching nexus might entail at the level of students and academics. This, in turn, could help policy makers to better direct their universities' policies so as to strengthen the connection between research and teaching in their universities' educational practice.

\section{Studies on the research-teaching nexus}

In their meta-analysis, Hattie and Marsh (1996) used a correlational approach, finding little or no relationship between research and teaching. However, this approach has been criticised by Verburgh, Elen \& Lindblom-Ylänne (in press), because of its narrow focus on effectiveness and excellence in research and teaching, which were measured exclusively as productivity (output) and student ratings, respectively. This approach, indeed, has limited potential to assess the reciprocal relationship between research and teaching; in this section, therefore, empirical research is addressed on how academics and students perceive the research-teaching nexus to provide a better idea of possible benefits and disadvantages of strengthening the connection between research and teaching. Following this, the literature is discussed in which the researchteaching nexus is conceptualised and translated into educational practice, at both the curriculum level and the course level.

Empirical studies of academics' and students' perceptions and experiences of the research-teaching nexus

For most academics a strong connection between research and teaching is seen as an essential part of their job satisfaction. Most would not like to work at an exclusive research institution and even fewer at an institution devoted entirely to education (Jensen, 1988). In his interview study, Jensen (1988) identified three different types of perceptions of 
how teaching can benefit from research. First, research fertilises teaching with new topics and methodological advances. Second, research provides teachers with a personal engagement of great pedagogic significance. Third, academic staff research guarantees connections with developments in the world of international research. Dominant responses on the significance of teaching to research were the following: teaching provides a breadth of practice within the subject, outside the narrow field of research; and new students are a stimulating form of pressure. Important is the clear indication of an asymmetry in the interrelationship, as the influence of research on teaching seems much greater than vice versa. The characteristics of the connection between research and teaching appeared to vary between levels of teaching and between disciplines.

More recently, Coate, Barnett and Williams (2001) found a range of relationships between research and teaching, both positive and negative. While, ideally, many academics perceive a positive, synergistic relationship, in practice a number of factors may cause a negative influence of research and teaching on each other. These factors include management strategies and pressures from accountability and funding mechanisms, leading to a compartmentalisation of teaching and research. For instance, universities often value research more (that is, career perspectives), whereas at the same time the facilities to do research (especially time) are limited, because of high teaching demands.

Robertson and Bond (2005) interviewed academics about their perceptions of the research-teaching nexus. It became clear that the epistemological framework of the participants determined their experiences with, and approaches to, research and teaching (Robertson \& Bond, 2005). These frameworks appeared to be different for academics of different disciplines, reflecting various research traditions and teaching approaches. Consequently, these various frameworks imply differences in shaping the teaching-research nexus (Robertson, 2007).

The findings cited above show that, in general, academics view the connection between research and teaching positively, although, in practice, the potential benefits are not always realised. It also appears that the research-teaching nexus is conceived of in various ways by academics, who may have quite different conceptions of research and teaching. These differences appear to be related to their disciplinary background (Becher \& Trowler, 2001).

From research on students' perceptions and experiences (Jenkins et al., 2003), it is known that students are usually more motivated when they become familiar with the research done by academic staff at an early 
stage in their studies. For example, when staff incorporated their own research into their teaching, students perceived their courses as up to date, stimulating intellectual excitement and giving the impression that staff were enthusiastic about what they were teaching (Jenkins et al., 2003: 15). Also, student learning might improve because they feel part of a social group (Healey, 2005).

Seymour et al. (2004) reviewed the literature on benefits of research experiences for undergraduate students and interviewed a sample of science students $(n=76)$ about their experiences. They reported almost exclusively positive outcomes, such as students becoming more confident to do research, gaining more interest in their discipline, finding out what it's like to 'think and work as a scientist', improving specific skills (for example, critical thinking) and their understanding of the research process, and becoming part of the scientific community. In a follow-up study, Hunter et al. (2006) described the experiences of students and academics working collaboratively on a project of mutual interest in an apprenticeship of authentic science research work, finding that the students reported gains, such as personal and intellectual development, whereas academics viewed the gains as part of professional socialisation into the sciences.

Robertson and Blackler (2006) found in an interview study that students were proud to be studying in a research environment and were motivated by their lecturers' enthusiasm for research. Moreover, they were challenged by involvement in research-related activities. It was also clear that student awareness of, and engagement with, research varied between the disciplines they were studying.

Healey and colleagues (2003) summarised key findings of studies into students' perceptions of the relevance of research to their learning. The benefits of a close relationship students perceived were staff enthusiasm, credibility of staff and the reflected glory of being taught by known researchers. Moreover, they recognised that being actively involved in research increased their awareness of the nature and process of research and increased their research skills (Healey et al., 2003). Disadvantages were also noted. A major disadvantage of staff involvement in research, according to students, is the declining availability of staff to support them. Also, students often did not show much ownership of staff research activities because they were not much involved in these activities. Thus, they felt that academic staff research should not take priority over their other needs.

This brief review reveals that a strong connection between research and teaching has important potential benefits for students. At the same time, 
however, there may be disadvantages when students who are involved in research activities experience a lack of support and ownership.

\section{Conceptualisations of the research-teaching nexus}

Based on earlier studies of how academics conceptualise research, knowledge and teaching, Brew (2003) proposed two models of teaching in which a relationship with research is represented. She states that the model, which is current in most universities, is based on a conception of knowledge as objective and separate from knowers, whereas research is seen as the construction of bodies of knowledge and teaching is focused on the transmission of information to students. In this model, teaching and research 'constantly pull away from each other, vying for resources and academics' time' (Brew, 2003: 10). Brew argues in favour of a new model, based on a conception of knowledge constructed in a sociopolitical context, research conducted in academic communities of practice and teaching which is student-focused and aimed at conceptual change. An important feature of this new model is that, to enhance the connection between teaching and research, students should become members of academic communities of practice. This is consistent with some of the policy documents cited earlier.

Neumann (1992) identified a three-level nexus between teaching and research, based on the findings of her interview study mentioned earlier. First is the tangible nexus, which refers to knowledge acquired through research which is passed on to the students. Second is the intangible nexus, which is related to two issues: '(a) to the development in students of an approach and attitude towards knowledge, and (b) to providing a stimulating and rejuvenating milieu for academics' (Neumann, 1992: 162). Last is the global nexus, which implies that the research programme of the department influences the broad direction of undergraduate courses and reflects the academics' specialties. Neumann argues that, in general, the intangible nexus is more important in the first years of undergraduate programmes and the tangible nexus gradually becomes more important in later years.

Focusing on the curriculum level, Griffiths (2004) examined different forms of knowledge production in research and discussed the implications of these differences for teaching. In particular, Griffiths compared differences between research and knowledge production in technology (for example, built environment disciplines) and other fields. Taking these differences into account, he suggested that there are qualitatively 
different ways to strengthen the research-teaching nexus. In particular, he described the following curriculum models of the research-teaching nexus:

1. The curriculum can be research-led. This means that the content is selected on the basis of research interests of academic staff; teaching is mostly traditional, focusing on the transmission of information and emphasising the understanding of research findings rather than research processes.

2. The curriculum can be research-oriented, implying an emphasis on understanding the processes by which knowledge is produced in the field as much as on learning subject content; teaching focuses on inquiry skills and on acquiring a 'research ethos'.

3. The curriculum can be research-based which means that it contains many activities in which students actually conduct research (for example, projects); these activities are based on authentic processes of inquiry (they are connected to the research of the institute); the division of roles between academic staff and student is minimised.

4. The curriculum can be research-informed in the sense that it is designed and constantly adapted on the basis of results of systematic inquiry into the teaching and learning process itself. In this mode, the 'scholarship of teaching' refers to teachers who are actively involved in designing and researching their own courses (Boyer, 1997). Unlike the other three, this model focuses on educational research rather than disciplinary research.

Building on the work of Griffiths, Healey (2005) explored the various ways in which the research-teaching nexus is understood, also in less research-intensive higher education institutes. According to him, these various ways primarily reflect differences in the way that the terms 'research' and 'teaching and learning' are conceptualised and, secondly, are associated with different disciplinary cultures in which research and teaching take place (Neumann et al., 2002; Robertson \& Bond, 2005). Healey argues that the connection between teaching and research can be constructed along three dimensions, according to whether (1) the emphasis is on research content or research processes and problems, (2) the students are treated as the audience or participants, (3) the teaching is teacher-focused or student-focused (Trigwell \& Prosser, 2004). Combining these dimensions with the distinction made by Griffiths, Healey arranged four qualitatively different views on the research-teaching nexus in a two-dimensional space. The vertical axis runs from studentfocused activities with students as participants to teacher-focused 


\section{STUDENTS AS PARTICIPANTS STUDENT-FOCUSED}

\begin{tabular}{|c|c|c|c|}
\hline & $\begin{array}{l}\text { Research-tutored } \\
\text { Curriculum } \\
\text { emphasises } \\
\text { learning focused } \\
\text { on students writing } \\
\text { and discussing } \\
\text { papers or essays }\end{array}$ & $\begin{array}{l}\text { Research-based } \\
\text { Curriculum } \\
\text { emphasises } \\
\text { students } \\
\text { undertaking } \\
\text { inquiry-based } \\
\text { learning }\end{array}$ & $\begin{array}{l}\text { EMPHASIS ON } \\
\text { RESEARCH }\end{array}$ \\
\hline $\begin{array}{l}\text { ON } \\
\text { RESEARCH } \\
\text { CONTENT }\end{array}$ & $\begin{array}{l}\text { Research-led } \\
\text { Curriculum is } \\
\text { structured around } \\
\text { teaching subject } \\
\text { content }\end{array}$ & $\begin{array}{l}\text { Research-oriented } \\
\text { Curriculum } \\
\text { emphasises teaching } \\
\text { processes of } \\
\text { knowledge } \\
\text { construction in the } \\
\text { subject }\end{array}$ & $\begin{array}{l}\text { PROCESSES } \\
\text { AND } \\
\text { PROBLEMS }\end{array}$ \\
\hline
\end{tabular}

\section{STUDENTS AS AUDIENCE TEACHER-FOCUSED}

Figure 1 Curriculum design and the research-teaching nexus (According to Healey, 2005).

activities with students as the audience and the horizontal axis from an emphasis on research content to an emphasis on research processes and problems (Figure 1).

Omitting the research-informed variety described by Griffiths, Healey identified the top left quadrant as student-focused and emphasising research content, stating that this variety 'is perhaps best illustrated by the Oxbridge tutorial system, where students engage in discussion with their tutors producing, in Oxford, an average of three papers or essays a fortnight [ . . . . "Research-tutored", although slightly clumsy, might be an appropriate description to put alongside Griffiths' other categories' (Healey 2005: 69). Placing the research-led and the research-oriented modes at the bottom of Figure 1, Healey considers teaching in these varieties to be mostly teacher-focused, with the students in the role of audience, rather than participants in research. The distinction between these two, according to Healey, is that the emphasis is on research content in the research-led mode and on research processes in the research-oriented variety. In the research-based mode, finally, teaching is 
considered to be student-focused, with students participating in research, focussing on research processes and problems, which explains why this type is located in the top right quadrant.

In summary, it appears there are various ways to conceptualise the connection between research and teaching. These ways can be distinguished according to the role of the students (for example, to what extent do students engage in research activities?) and by an emphasis on either research content, or research processes and problems. Healey's distinction, in particular, seems useful for characterising various ways to strengthen the research-teaching nexus, in the context of curriculum design and the design of undergraduate courses. In the following section, the possible uses of Healey's distinction in these contexts is discussed.

\section{Implications for curriculum and course design}

\section{Course level}

Before turning to the design of courses, Healey's distinction is used as a tool to analyse existing undergraduate courses focusing on the way the research-teaching nexus is implemented. Four courses were taken from various contexts, which were initially considered (archetypical) illustrations of the four types distinguished by Healey. An important selection criterion was that these examples are known as best practices of courses in which research places a central role. This was evidenced in internal reports of the respective universities (Palfreyman, 2001; Ruis, 2007). Furthermore the aim was to cover a diverse range of subject matter courses. All courses were taken from curricula of research-intensive universities, as this constitutes the context of the study.

The four selected courses were:

1. Kaleidoscope, a series of presentations by physics and astronomy researchers, in which teachers present their research after which discussions with students are held (Leiden University, The Netherlands).

2. Field research, a simulation of anthropological field research in which second-year students practice their research skills (Leiden University, The Netherlands).

3. Undergraduates Research Opportunities Program (UROP), in which students carry out their own research proposal (if selected), which expects them to contribute to their field of research (MIT);

4. The Oxford Tutorial System, weekly meetings between tutors and their students to discuss students' work. 
The analyses were mainly based on course documents, syllabi and course evaluations. The analysis consisted of a thorough examination with respect to the following course characteristics. To start the analysis, the objectives of a course were identified. Next, a description was given of what teachers and students do to achieve these objectives and, finally, the actual course outcomes were assessed:

- The course objectives or aims. For instance, was the emphasis on understanding or developing the content of specific topics or concepts, or on acquiring specific research skills or attitudes, or on a combinations of these?

- The role of the teacher. For instance, did the teacher explicitly demonstrate specific aspects of the research outcomes, or processes in his or her discipline, or did the teacher supervise students' research activities?

- The students' learning activities. For instance, did these mostly consist of reading and analysing the research literature, or did students plan and conduct (small-scale) research projects, analysing data and presenting the outcomes of their projects?

- The course outcomes. To what extent were the course objectives realised in practice? What other outcomes were deemed important?

Individual analyses of the four courses, focusing on these characteristics, were compared and discussed by the authors until agreement occurred (Janesick, 1994).

The outcomes of the analyses of these four courses are depicted in a way that summarises the characteristics of the course objectives, the teacher's role, the learning activities and the course outcomes (see Table 1).

The findings revealed some discrepancies between the examples and Healey's four types. In particular, the following issues concerning Healey's conceptualisation of the research-teaching nexus emerged.

Consistent with Healey's idea, it was possible to distinguish between examples with a focus on content, that is, the outcomes of research (Kaleidoscope and Oxford tutorials, where students write essays and papers focusing on understanding of the content) and examples with a focus on the research process (Field research, where all steps in the research cycle are explicitly addressed and the Undergraduate Research Opportunities Program (UROP)). Clearly, in all these examples both outcomes and processes are important but the emphasis appeared to be on one.

Students played an active role in all examples. For instance, in the research-led example (Kaleidoscope), students were not a passive audience but discussed the presentations and wrote essays about the topics, 


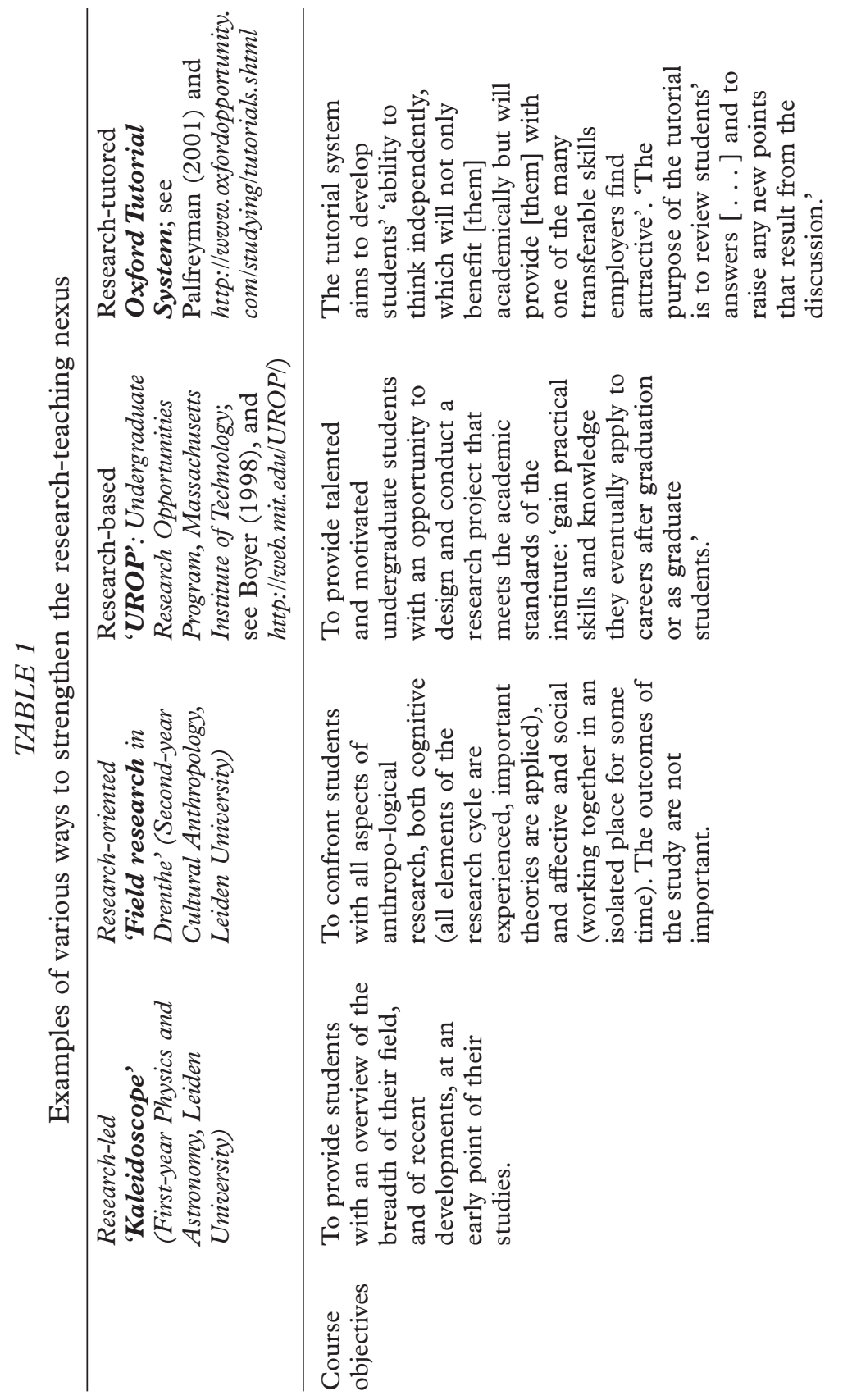




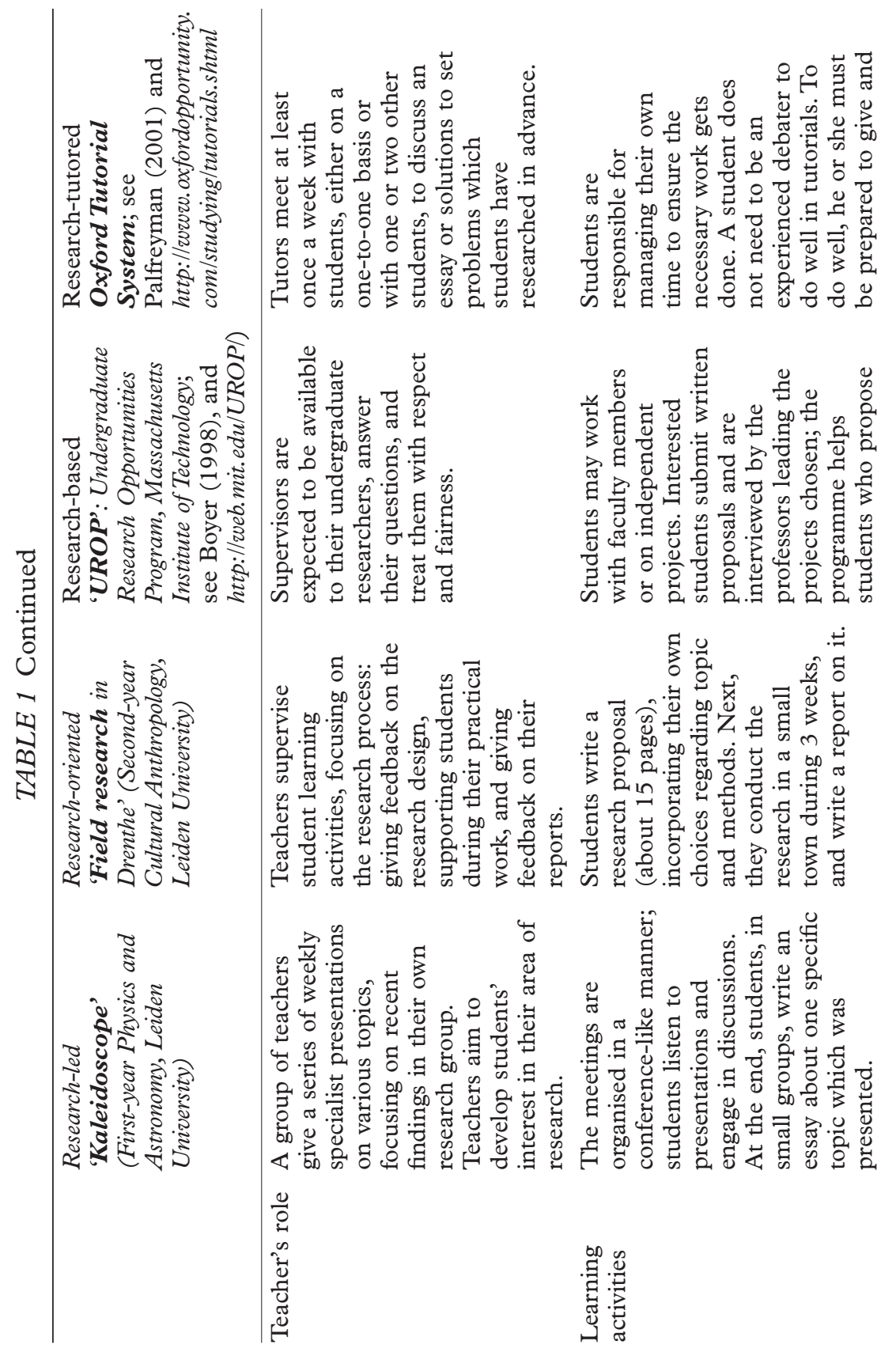




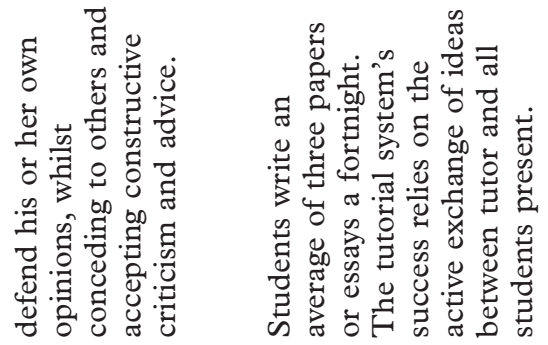

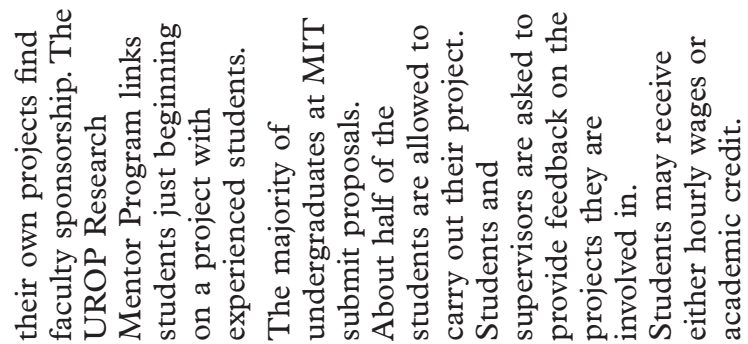
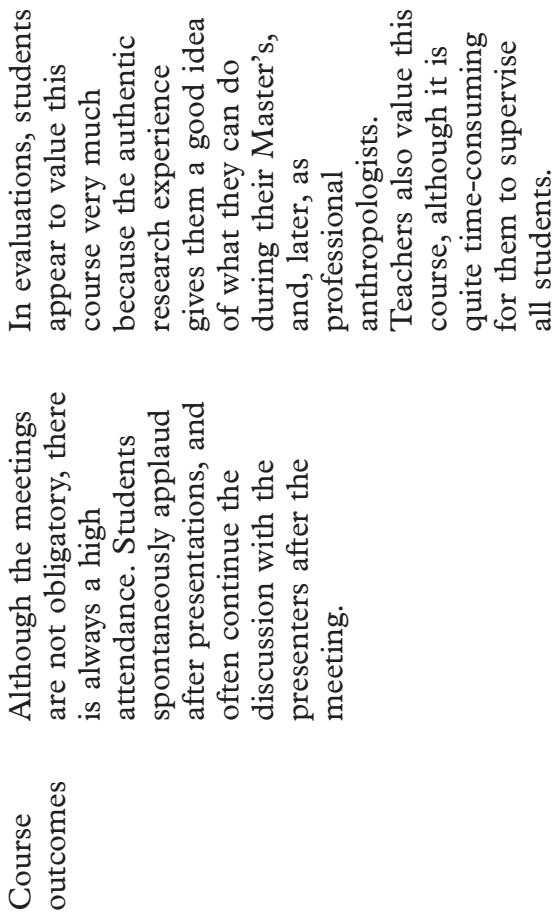
supervised by teaching staff. Therefore, it seems impossible to divide these examples into either teacher-focused or student-focused. Although in different ways, all examples had an explicit focus on student learning. This finding may be related to the selection criteria (best practices from research intensive universities). There was a distinction, however, between examples where teachers' own research played a central role (Kaleidoscope and, in some cases, UROP) and examples where research conducted elsewhere, or by others, was the focus of attention.

Related to the above, it was not always easy to place the examples in the 'upper' or the 'lower' part of Healey's scheme. In the end, the criterion was used that, in the research-based and research-tutored varieties, there should be an element of students developing new findings or insights for their disciplines, either by doing 'new' research (UROP), including re-testing of earlier outcomes, or by defending their own opinions (Oxford tutorials), including interpreting and re-integrating earlier research outcomes. In other words, students were considered to be 'participants in research' in a restricted manner, that is, if their participation led to understandings that are new to the field. In the other two examples, this was not the case. In the field research example, students developed knowledge that was new to themselves. However, similar research projects were conducted many times by previous cohorts of students and the outcomes were not deemed important or interesting by the academic staff. From the view described above, students, although they conducted research activities, were considered in these examples 'audience in research.'

The findings suggest an adaptation of Healey's scheme (see Figure 2). The 'process'-'content' dimension (the horizontal axis) was clearly helpful in distinguishing between the different courses, so this dimension was not altered. However the vertical axis raised problems. As only 'best practices' were selected, all courses were student-focused, in the sense that students were active (albeit in different ways) and that student learning was the focus of attention. Therefore, it was decided to leave out the 'teacher-focused' and 'student-focused' labels (Note that in a recent publication by Jenkins et al. (2007), these labels have also been dropped). The 'audience' versus 'participants' labels were useful, however, as discussed above, when these were interpreted as 'knowledge reception' and 'knowledge production', respectively. In other words, the difference between 'audience' and 'participants' should not be related to being passive or active, but to activities leading to different outcomes, that is, existing versus new insights. The descriptions of each quadrant 


\section{STUDENTS AS PARTICIPANTS}

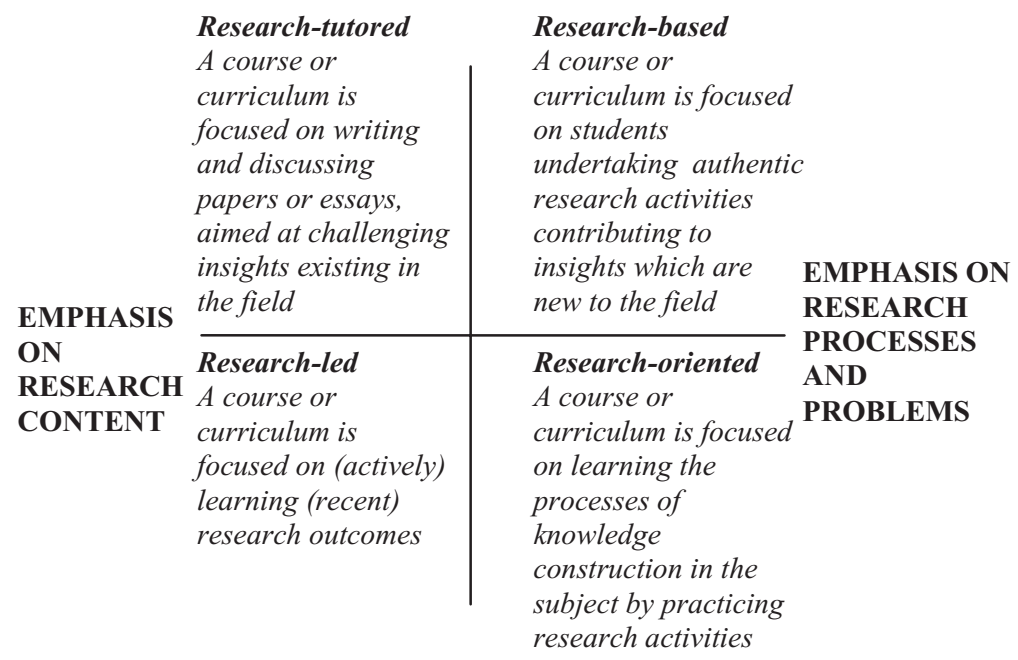

STUDENTS AS AUDIENCE

Figure 2 Curriculum design and the research-teaching nexus (Adapted from Healey, 2005).

was changed, also broadening the scope to encompass both the curriculum and the course level (Figure 2).

The above findings were translated into ideas that can be used to design undergraduate courses aimed at strengthening the researchteaching nexus. Such courses require a design that actively engages students in learning activities. Depending on the aim of a course, the emphasis can be either on promoting students' understanding of research products or processes that are already known within the research community (lower part of Figure 2), or on challenging them to contribute new facts or ideas (upper part). Furthermore, the focus of the activities can be either on gaining an understanding of (recent) research outcomes (left part of Figure 2), or on research processes and problems (right part). Finally, a course can concern the research of academics in the institute, or research that was done elsewhere, however, this distinction cannot be indicated in the two dimensional design of Figure 2.

In practice, courses can consist of a combination of activities with various emphases. For instance, a course can start with a lecture on a specific problem, or a recent research result and then discuss various 
ways to research this issue, after which students do some research in small groups and, in a concluding session, are debriefed by their teacher. The main aim of a course should determine in which category it belongs. Accordingly, students should spend a high proportion of their time on activities which fit into this same category (Healey, 2005: 71).

\section{Curriculum level}

To capture all different learning goals, a curriculum should consist of a mixture of courses designed according to different ideas (for example, research-led as well as research-based), consistent with the aims of the respective courses. Which mixture is the most appropriate depends on various factors, such as the aims of the curriculum as a whole (for example, training students for a research career, or for jobs in business or administration), the numbers and capacities of students enrolling in the curriculum and the nature of the disciplines, which may have very different research orientations and traditions.

To strengthen the research-teaching nexus at the curriculum level, a well-considered mix of courses, according to Healey's categorisation, is needed. Some aspects of the research-teaching nexus need to be given particular attention throughout the curriculum in a longitudinal and gradual way. These aspects might include the development of certain competencies that are important in research (for example, learning to work together, communication and presentation skills). Such competencies have been labelled 'generic graduate attributes' (Barrie, 2006). Also, it seems important to develop students' scientific research dispositions and their critical attitude towards knowledge. This is similar to Neumann's 'intangible nexus' (Neumann, 1992). This can be done in various ways, for instance, by including courses on the history and philosophy of the discipline in the curriculum, or by discussing the status of knowledge of a certain topic during a lecture: How was this knowledge developed? Are competing or alternative models used by scholars, or has this occurred in the past? Another issue concerns ethical questions related to doing research. Griffiths (2004) used the term 'research ethos' for this issue. For instance, how to deal with persons or animals as objects of research? Or the boundaries of what researchers should be allowed to investigate might be discussed.

Figure 3 presents a generic design of the first year of a researchintensive undergraduate curriculum consisting of the elements discussed above. This fictional curriculum includes courses aimed at developing basic knowledge and skills, for instance, through lectures and workshops. 


\begin{tabular}{|c|c|c|c|}
\hline Semester 1 & $\begin{array}{l}\text { An overview of the field } \\
\text { Series of lectures on various issues at a } \\
\text { basic level. Lecturers explicitly pay } \\
\text { attention to the research base of the } \\
\text { knowledge under consideration. } \\
\text { Students follow lectures and conduct } \\
\text { self-study, culminating in written } \\
\text { examinations (research-led). }\end{array}$ & $\begin{array}{l}\text { Tutorials, aimed at } \\
\text { critically discussing } \\
\text { research-based } \\
\text { knowledge in the field } \\
\text { (research-tutored). }\end{array}$ & $\begin{array}{l}\text { Research skills } \\
\text { Training sessions and workshops, } \\
\text { focusing on specific skills and } \\
\text { techniques, including } \\
\text { communicative skills (research- } \\
\text { oriented). } \\
\text { Research project 1: 'On familiar } \\
\text { territory,' aimed at experiencing all } \\
\text { steps in a research process and } \\
\text { reflecting on the research process, } \\
\text { including ethical issues, resulting in } \\
\text { a written group report (research- } \\
\text { oriented). }\end{array}$ \\
\hline Sem & $\begin{array}{l}\text { An overview of the research of the } \\
\text { institute. Series of conferences on } \\
\text { various topics which are investigated in } \\
\text { the institute. Students interview } \\
\text { academics and write a group report on a } \\
\text { topic of their choice (research-led). } \\
\text { History and philosophy of the discipline } \\
\text { Lectures focusing on knowledge } \\
\text { construction in the field, followed by } \\
\text { individual assignment where students } \\
\text { write an essay about a topic of their } \\
\text { choice (research-oriented). }\end{array}$ & $\begin{array}{l}\text { Tutorials, aimed at } \\
\text { critically discussing } \\
\text { research-based } \\
\text { knowledge in the field, } \\
\text { analysing and } \\
\text { comparing different } \\
\text { sources of knowledge, } \\
\text { and explicitly } \\
\text { addressing the status of } \\
\text { knowledge } \\
\text { (research-tutored). }\end{array}$ & $\begin{array}{l}\text { Advanced research skills } \\
\text { Training sessions and workshops, } \\
\text { focusing on specific skills and } \\
\text { techniques, including } \\
\text { communicative skills (research- } \\
\text { oriented). } \\
\text { Research project 2: 'Exploring the } \\
\text { boundaries,' aimed at participating } \\
\text { in research of the institute, resulting } \\
\text { in an oral presentation and a written } \\
\text { reflection on the research process } \\
\text { (research-based). }\end{array}$ \\
\hline
\end{tabular}

Figure 3 The two first semesters of a possible research-intensive curriculum

These courses in which students are 'audience' (lower part of Figure 2) are aimed at providing students with the knowledge and skills they need before they can engage in research.

The curriculum design in Figure 3 contains courses from all four quadrants in Figure 2. Among others, it consists of the following imaginary courses. First, to provide students with an overview of the research conducted in their institute, a series of conferences are held in which researchers present recent research outcomes. This activity is labelled research-led, because the aim is to familiarise students with the content of the research, for example, by interviewing academics.

Next, throughout both semesters, a series of tutorials is thought to be organised. These are labelled research-tutored, because the emphasis is on the content of research outcomes, whereas students are expected to discuss the content in such a way that they may contribute to new ideas or perspectives with regard to this content. Tutors are expected to challenge students to ask questions regarding the content, to the point where they are not able to answer these and it is necessary for both students and tutor to look for answers in various sources of information. Clearly, there is a progression of the content over time, such as increasing complexity, or the use of more advanced information sources.

Also, in each semester there is a research project. The first, which is given the name On familiar territory, is focused on students experiencing 
all steps and aspects of research processes and problems in the discipline. Because the outcomes of the projects are known to the staff and students are not expected to generate new ideas regarding the research process, nor the outcomes, this project is labelled research-oriented, even though students are actively engaged in research activities. In the project in the second semester, named Exploring the boundaries, however, students actually participate in the research of the institute, for instance, working together with $\mathrm{PhD}$ students, collecting data, or analysing existing data. In this way, students become members of the aforementioned 'community of scholars'. Their participation may contribute to the advancement of insights into the research process, or even generate new outcomes, hence this project is labelled research-based.

\section{Toward implementation of research-intensive education}

Any university should make choices that allows it to develop its own educational profile as an institute where research and teaching are connected. Overall, a university that chooses to strengthen the researchteaching nexus should increase the proportion of research-based and research-tutored courses in their curricula. Put differently, they should move 'up' in Figure 1 or 2, putting students more often in the role of participants in research. Since disciplines have their own traditions, resulting in different research approaches, methodologies and cultures (Becher \& Trowler, 2001), which influence the ways in which the connection between research and teaching is shaped (Robertson, 2007), curricula may have different orientations. For instance, curricula in the humanities are probably more geared towards a research-tutored orientation, whereas curricula in the natural sciences are likely to opt for a research-based orientation. Moreover, there are also differences in student enrolment and staff-student ratios. For instance, it will be easier for some departments to implement tutorials than for others, owing to a relatively greater availability of staff. As a consequence, there will be differences within an institute between disciplines and departments in the ways they translate the educational profile of their institute into the curricula and courses of their undergraduate programmes.

As stated in the introduction, although many universities have formulated a general policy about connecting teaching and research at the institutional level, it is often not clear in what ways and how often, such connections are actually being made in the curricula of various disciplines. To improve the relation between policy and practice, Jenkins and Healey (2005) have proposed four groups of institutional strategies. 
The first group is aimed at developing the institutional mission and increasing awareness within the institute of this mission. Among the strategies in this group are the organisation of specific events for academics, students and even their parents, to promote awareness and create commitment to the institute's mission. In this way, the university's mission should become better embedded in the practice of teaching. The second group is aimed at curricula and courses and includes auditing teaching policies, courses, or departments, as well as reviewing the timetable, for example, to create blocks of time in which students can do research. The third group of strategies is aimed at staff involvement, for example, by engaging high-level researchers in undergraduate programmes. The fourth and final group of strategies is aimed at the professional development of academics, for instance, by bringing research and teaching together in doctoral training. To complement this, promotion and reward policies should encourage academics to improve connections between research and teaching.

As for programmes aimed at the professional development of academics, these should take the academics' beliefs as a starting point. That is, if the aim is to strengthen the connection between research and teaching, a thorough understanding is needed of how academics perceive and experience this relationship in the context of the culture of the discipline in which they are educated and working (Robertson \& Bond, 2005). Academics' existing beliefs should be developed in order to promote changes in their teaching practice (Beijaard et al. 2000). This can be done by supporting academics in designing courses in a researchintensive manner and providing them with opportunities to experiment with various ways of strengthening the research-teaching nexus. Reflecting on these experiments, and sharing experiences with colleagues, can be a productive way to further develop research-intensive education.

In any case, it is important that activities and policies aimed at strengthening the university's profile are consistent with initiatives at the level of disciplines and departments and, vice versa, that academics and departments are stimulated and facilitated to develop ways to strengthen the research-teaching nexus that are consistent with the institute's mission.

\section{References}

Academic Strategy - A Green paper (2005), Oxford, Oxford University.

Barrie, S. C. (2006), Understanding what we mean by generic attributes of graduates. Higher Education, 51 (2), pp. 215-241. 
Becher, T., \& Trowler, P. R. (2001), Academic Tribes and Territories; Intellectual enquiry and the cultures of disciplines, second edition, Buckingham, The Society for Research into Higher Education \& Open University Press.

Beijaard, D., Verloop, N., Wubbels, Th., \& Feiman-Nemser, S. (2000), The professional development of teachers. In R. J. Simons, J. van der Linden, \& T. Duffy (Eds.), New learning (pp. 261-279), Dordrecht, Boston, London, Kluwer Academic Publishers.

Boyer, E. (1997), Scholarship reconsidered: Priorities of the professorate, Princeton, NJ, Carnegie Foundation for the Advancement of Teaching.

Boyer Commission (1998), Reinventing Undergraduate Education: A Blueprint for America's research universities, Stony Brook, NY, Carnegie Foundation for University Teaching.

Brew, A. (2003), Teaching and Research: New relationships and their implications for inquiry based teaching and learning in higher education. Higher Education Research and Development, 22(1), pp. 3-18.

Coate, K., Barnett, R., \& Williams, G. (2001), Relationships between teaching and research in higher education in England. Higher Education Quarterly, 55, pp. 158-174.

Colbeck, C. L. (1998), Merging in a seamless blend: How faculty integrate teaching and research. The fournal of Higher Education, 69 (6), pp. 647-671.

Griffiths, R. (2004), Knowledge production and the research-teaching nexus: The case of the built environment disciplines. Studies in Higher Education, 29(6), pp. 709-726.

Hattie, J., \& Marsh, H. (1996), The relationship between research and teaching: A metaanalysis. Review of Educational Research 66(4), pp. 507-542.

Healey, M., Jordan, F., Pell, B., \& Short, C. (2003), The student experience of research and consultancy. SEDA-Society for Research into Higher Educational Joint Conference on The Scholarship of Academic and Staff Development: Research, Evaluation and Changing Practice, Bristol, 9-11 April 2003.

Healey, M. (2005), Linking research and teaching: Exploring disciplinary spaces and the role of inquiry-based learning. In Barnett, $\mathrm{R}$ (Ed.), Reshaping the University: New Relationships between Research, Scholarship and Teaching, pp. 67-78, London, McGraw Hill / Open University Press.

Hunter, A. B., Laursen, S. L., \& Seymour, E. (2006), Becoming a scientist: The role of undergraduate research in students' cognitive, personal, and professional development. Science Education, 91, pp. 36-74.

Janesick, V. J. (1994), The dance of qualitative research design. In N. K. Denzin \& Y. S. Lincoln (Eds.), Handbook of Qualitative Research Design (pp. 209-219), Thousand Oaks: Sage.

Jenkins, A., Breen, R. \& Lindsay, R. (2003), Reshaping teaching in Higher Education, linking Teaching with Research, London, Kogan Page Limited.

Jenkins, A., \& Healey, M. (2005), Institutional strategies to link teaching and research, York, The Higher Education Academy.

Jenkins, A., Healey, M., \& Zetter, R (2007), Linking teaching and research in departments and disciplines, York, UK, The Higher Education Academy.

Jensen, J. (1988), Research and Teaching in the universities of Denmark - does such an interplay really exist. Higher Education, 17(1), pp. 17-26.

Leiden University (2004). Kiezen voor talent [Focusing on talent], Leiden, Leiden University.

Neumann, R. (1992), Perceptions of the teaching-research nexus: A framework for analysis. Higher Education, 23(2), pp. 159-171.

Neumann, R., Parry, S., \& Becher, T. (2002), Teaching and learning in their disciplinary contexts: A conceptual analysis. Studies in Higher Education, 27(4), pp. 405-417.

Palfreyman, D. (2001), The Oxford Tutorial, 'Thanks you thought me how to think'. Oxford, OxCHEPS.

Robertson, J., \& Bond, C. (2005), The research/teaching relation: A view from the edge. Higher Education, 50, pp. 509-535. 
Robertson, J., \& Blackler, G. (2006), Students' experiences of learning in a research environment. Higher Education Research E Development, 25 (3), pp. 215-229.

Robertson, J. (2007), Beyond the 'research-teaching nexus': exploring the complexity of academic experience. Studies in Higher Education, 32(5), pp. 541-556.

Ruis, P. (2007), Praktijkvoorbeelden van Research Intensief Onderwijs aan de Universiteit Leiden [Examples of practice of Research Intensive Education at Leiden University]. Leiden: ICLON, Universiteit Leiden.

Seymour, E., Hunter, A. B., Laursen, S. L., \& Deantoni, T. (2004), Establishing the benefits of research experiences for undergraduates in the sciences: First findings from a three-year study. Science Education, 88, pp. 493-534.

Simons, M., \& Elen, J. (2007), The 'research-teaching nexus' and 'education through research': an exploration of ambivalences. Studies in Higher Education, 32(5), pp. 617631.

Trigwell, K., \& Prosser, M. (2004), Development and use of the approaches to teaching inventory. Educational Psychology Review, 16, pp. 409-424.

University of Helsinki (2007), Top research across a broad front (Available at: http://www. helsinki.fi/excellence/index.html).

Verburgh, A., Elen, J., \& Lindblom-Ylänne, S., The nature of the empirical research on the relation between teaching and research. Fournal of Philosophy and Education (forthcoming). 